Tjalling C. Koopmans Research Institute

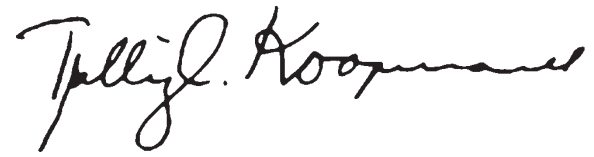

Discussion Paper Series nr: 10-03

\title{
Gender Diversity and Firm Performance: Evidence from Dutch and Danish Boardrooms
}

Joana Marinova Janneke Plantenga

Chantal Remery 


\title{
Tjalling C. Koopmans Research Institute Utrecht School of Economics \\ Utrecht University
}

Janskerkhof 12

3512 BL Utrecht

The Netherlands

telephone $\quad+31302539800$

fax +31302537373

website www.koopmansinstitute.uu.nl

The Tjalling C. Koopmans Institute is the research institute and research school of Utrecht School of Economics.

It was founded in 2003, and named after Professor Tjalling C. Koopmans, Dutch-born Nobel Prize laureate in economics of 1975.

In the discussion papers series the Koopmans Institute publishes results of ongoing research for early dissemination of research results, and to enhance discussion with colleagues.

Please send any comments and suggestions on the Koopmans institute, or this series to J.M.vanDort@uu.nl

ontwerp voorblad: WRIK Utrecht

\author{
How to reach the authors \\ Please direct all correspondence to the second author. \\ Joana Marinova \\ Janneke Plantenga \\ Chantal Remery \\ Utrecht University \\ Utrecht School of Economics \\ Janskerkhof 12 \\ 3512 BL Utrecht \\ The Netherlands. \\ E-mail: c.l.h.s.remery@uu.nl
}




\title{
Gender Diversity and Firm Performance: Evidence from Dutch and Danish Boardrooms
}

\author{
Joana Marinova \\ Janneke Plantenga \\ Chantal Remery
}

Utrecht School of Economics

Utrecht University

January 2010

\begin{abstract}
Drawing on the business case for gender diversity, this article examines whether board gender diversity has a positive effect on firm performance, based on evidence from the Netherlands and Denmark. We use empirical data on 186 listed firms observed in 2007, of which 102 Dutch and 84 Danish. Of these firms, almost 40\% have at least one woman in the boardroom. Within boards the average share of women is only $5.4 \%$. In order to investigate the impact of board gender diversity on firm performance, two-stage least-squares estimation is applied, using Tobin's Q as a measure of performance. Our findings indicate that there is no effect of board gender diversity on firm performance. This implies that the business case for board gender diversity is not supported for this particular sample. Our finding seems in line with most European research.
\end{abstract}

Keywords: Corporate governance, firm performance, board diversity, female board representation

JEL classification: G34, J16 en L25. 


\section{Introduction}

Gender diversity in the boardroom and in top executive positions has been the focus of public debate, academic research, government considerations and corporate strategy for more than a decade now. Previously considered a social issue and an issue of image, gender diversity is increasingly approached as a value-driver in organisational strategy and corporate governance, and as such has become a challenging issue in recent academic research. Positive performance effects of board gender diversity imply that a higher number of women in corporate top positions or on board of directors will relate to increased firm productivity and profitability.

Among the first to formulate and support the business case argument for women in top management were the researchers from Catalyst (2004), who showed that more diverse companies achieve better financial results. Since then, interest in the business case for recruiting, developing and advancing women has been growing. Several research and advisory organizations are active in this field. Catalyst, for example, is represented in the US, Canada and Switzerland and works with partner organizations on several continents, while the European Professional Women's Network (EuropeanPWN) carries out Europe-wide initiatives. Despite debates, action programs and media attention, however, women in the EU represent only $11 \%$ of boards of directors and supervisory boards (Desvaux, Devillard-Hoellinger and Meaney 2008). In its third bi-annual European Board Women Monitor 2008, the EuropeanPWN observed that in the 300 largest companies in Europe the overall progress of women to the boardrooms remains slow. According to the Monitor, the average European board consists of 15.1 members, of which 1.5 are women (EuropeanPWN 2008).

In order to increase the number of women in top positions, affirmative actions are under 
discussion or already operational in several countries. In Norway, for example, from 2006 onwards large firms must have at least $40 \%$ female representation among the members of the board of directors, as a result of which Norway currently scores $44.2 \%$ female board representation (EuropeanPWN 2008). In Finland, the new Corporate Governance Code of 2008 requires that from January 12010 Finish listed companies have at least one female board director, or if not, explain the reasons why (www.europeanpwn.net).

At the same time, formal literature on the business case argument is rather thin, especially within the European context. As a result, the business case argument for gender diversity, suggesting that diversity translates into better decisions and ultimately in better products, is seldom made on the basis of firm, scholarly research. In order to contribute to the scientific debate this article addresses the question whether board gender diversity indeed has a significant positive effect on firm performance, using data for 186 listed firms observed in 2007, of which 102 Dutch and 84 Danish. Denmark and the Netherlands were chosen as these two countries have similar corporate governance structures, using a two-tier system with a management board and a supervisory board. The management board is made up of executive directors and is responsible for the daily management of the company and decision-making. The supervisory board consists of non-executive directors and mainly deals with supervising the policy of the management board, ratifying managerial decisions, providing advice, as well as adopting the company's annual accounts (Corporate Governance Committee 2003; Committee on Corporate Governance 2005). The main difference between the two countries is that in Denmark a number of employee representatives may sit on supervisory boards, while the employees' role in Dutch boards is indirect, through the works councils. In terms of board gender diversity in Europe in 2008 Denmark and the Netherlands occupy the fourth and fifth place, respectively (EuropeanPWN 
2008). In Denmark the share of women on board of director was $18.1 \%$ in 2008 , as compared to $17.9 \%$ in 2006 , while in the Netherlands women's representation on board of directors almost doubled from its $6.5 \%$ in 2006 to $12.3 \%$ in 2008 - an impressive growth, which seems to be related to increased societal pressure and media attention (EuropeanPWN 2008).

As such, the aim of the article is twofold. First, it contributes to the limited European evidence on gender diversity and firm performance as until now most empirical research has focused on US companies. Secondly, the article will contribute to the scientific debate by applying a methodology that allows for correct analysis of the relationship between board gender diversity and firm performance. Analyzing this relationship is complicated as the direction of causality can be twofold; that is more female board directors may contribute to higher firm performance, but it might also be the case that better-performing firms tend to appoint more women on their boards. By taking this complication into account, the results of the analysis will be more robust and thus more reliable.

\section{Theoretical background and recent empirical findings}

Within a corporate governance framework, the composition of corporate boards is crucial to aligning the interest of management and shareholders, to providing information for monitoring and counselling, and to ensuring effective decision-making (Becht, Bolton and Röell 2002; Hermalin and Weisbach 2003). Gender diversity, together with board size, age dispersion and the share of directors chosen by the employees, all relate to board decision-making processes (Bøhren and Strøm 2007). Whether board diversity influences firm performance in a positive or negative way, however, is theoretically undetermined a priori. In more general terms, Becht et al. (2002, p. 24) conclude that the formal literature on board design is 'surprisingly thin'. 
A major argument in support of management diversity is that a more diverse board of directors may take decisions while considering a wider range of alternatives. Carter, Simkins and Simpson (2003) and Carter, D’Souza, Simkins and Simpson (2008) enumerate several positive propositions of the business case for board gender diversity, among which this is a central one. Within the 'upper echelons' theory, heterogeneous top management teams relate to more creative idea generating, and are thus linked to more innovative organizations (Jackson 1992).

Summarizing several of the positive theoretical underpinnings for diversity Smith, Smith and Verner (2006) elaborate the arguments and provide intuitive examples. Firstly, women directors may better understand particular market conditions than men, which may bring more creativity and quality to board decision-making. Secondly, a more gender diverse board may generate a better public image of the firm and, through this, improve firm performance. Thirdly, it is possible that the external talent pool for board members increases once women have been appointed to particular executive positions. Furthermore, research shows that the number of female top managers may influence positively the career development of women in lower positions, thus boosting firm productivity directly as well as indirectly-i.e. by enlarging the internal pool of candidates for top positions.

In addition to benefits, management diversity may also bring costs. Coordination of diverse top management teams may be more difficult and costly, and any possible increase in performance may not be high enough to ultimately offset these increased costs (Ancona and Caldwell 1992). A heterogeneous board may slow down decision-making as the likelihood of reaching consensus may be smaller. The result will be a less efficient decision-making body, which may turn out to critically impede a firm's competitive behaviour (Hambrick, Cho and Chen 1996). While it appears that larger boards tend to be more diverse, Jensen (1993) argued 
that too big boards become less efficient in controlling management, and thus face more agency problems resulting from the separation of ownership and control. Similarly, Yermack (1996) and Eisenberg, Sundgren and Wells (1998) have documented that board size and firm performance are inversely correlated.

Most of the empirical evidence comes from the US, where studies focus mainly on the largest firms. In a study of large US public companies in various industries Erhardt, Werbel and Shrader (2003) found that diversity of the executive board of directors was positively related to both return on investment and return on assets. Kochan et al. (2003) observed only few direct effects - both positive and negative - of management gender diversity, and emphasized the crucial role of organizational context and group processes as moderators. A positive correlation was found by Adler (2001) and Catalyst (2004) studying US Fortune 500 firms. Examining the relationship between the percentage of women and minorities on boards of directors and firm value, a significantly positive effect is also found by Carter et al. (2003, 2008). Dwyer, Richard and Chadwick (2003) drew the attention to the moderating role of the firm's strategic orientation and organizational culture. In their study of 535 US banks they found that firms that focused on growth experienced positive performance effects from gender diversity. In addition, a positive association was observed to some extent in a clan culture context which is characterized by core values such as teamwork and participation. However, the performance effects of gender diversity appeared to be significantly negative within the setting of an adhocracy culture, which is characterized by an external orientation and a focus on individuality and competition. Frink et al. (2003) established an inverted U-shape curvilinear relationship between gender diversity and organization performance for several of the sectors studied. Their results suggest that there is an optimum regarding gender composition. In a recent panel study of top 1,500 US public 
companies Dezso and Ross (2008) found that having a female CEO had no positive effect on firm performance, while female participation below the CEO level was positively associated with firm performance for companies pursuing an innovation intensive strategy.

Whereas the results from US studies seem to be predominantly positive, European evidence appears to be mixed. Rose (2007) used a sample of Danish firms listed on the Copenhagen Stock Exchange during 1998-2001, and found that female board representation had no impact on firm performance. Smith et al. (2006) in a panel data study of 2,500 of the biggest Danish firms showed that the share of women among top executives and on boards of directors tended to have a significantly positive effect on firm performance, controlling for firm characteristics, as well as for the direction of causality. Furthermore their results revealed that the positive performance effects were mainly accounted for by female managers with university education, and were also related to female board members elected by the staff. Randøy, Thomsen and Oxelheim (2006) investigated the effect of board diversity on corporate performance, examining a sample of the largest companies from Denmark, Norway and Sweden, and found no significant gender diversity effect. Bøhren and Strøm (2007), studying a sample of Norwegian listed non-financial firms, seem to be the only researchers who found a significantly negative association between board gender diversity and firm performance.

Other evidence regarding the impact of women in top positions on firm performance is provided by Weber and Zulehner (2009). Arguing that first hires normally hold key positions in start-up firms, they found a positive association between the presence of at least one woman among the first hires in almost 30,000 Austrian start-up companies and companies' success measured by their survival. In addition, recent research in the UK has shown that having at least one female board director reduces the risk of bankruptcy (Wilson and Altanlar 2009). 
Investigating the role of gender has also been extended to the complicated context of mergers and acquisitions (M\&A). However, evidence is still very limited. Levi, Li and Zhang (2008)

examined the effects of female CEOs and corporate directors on the pricing and abnormal returns on 403 M\&A in the US. They showed that the presence of a female CEO in the bidding company and independent female directors in the target company reduced the bid premium paid, and were associated with lower cumulative abnormal returns in the target companies during the period of announcement of the M\&A event. Sudarsanam and Huang (2007) studied a sample of more than 2,500 acquisitions in the US and documented that the market initially responded favourably to M\&A deals concluded by female CEOs, however, this was reversed in the long run. In fact, Sudarsanam and Huang concluded that 'risky corporate acquisitions undertaken by female CEOs destroy shareholder's value in the long run' (2007, p. 21). In line with the predominantly positive association established by earlier research, we presume that also within the cross-national Dutch and Danish context board gender diversity will have a positive effect on firm performance.

\section{Sample and data}

Our sample comprised 186 listed companies in 2007, of which 102 Dutch companies listed on Euronext Amsterdam and 84 Danish companies listed on OMX Nordic Exchange Copenhagen. We focused on listed companies due to data availability considerations and the nature of our performance measure. Banks, insurance companies, and football clubs have been excluded as a result of their specific accounting, which poses difficulties for the calculation of the performance measure (Tobin's Q). Companies were also excluded in case of missing data for 2007. In addition, two Dutch companies were excluded as 'outliers' due to having extreme values of a variable or inputs to a variable. In this article the term 'board' is used to refer to the combined 
number of all directors, that is, management (executive) directors plus supervisory (nonexecutive) directors and the term 'supervisory directors' to refer specifically to the supervisory board. All companies in our samples except for one apply the two-tier system of corporate governance.

The main data source regarding board characteristics were companies' annual reports, supplemented by the AMADEUS database. AMADEUS contains financial information on over 11 million companies in Europe, including also information on board of directors. Data on directors, however, refer only to directors currently in office, while we needed to obtain information for 2007. Due to this database limitation, each company's annual report was meticulously checked and data on each director were manually collected from the companies' websites. Other public internet sources were used as supplementary sources. With respect to accounting and financial information, the source was Reuters' Datastream international financial statistical database. We converted all Danish companies' accounting figures into Euros, using the exchange rate applied in Datastream market capitalization data, and considering variations in companies' accounting periods. In principle all date refer to the situation on 31 December 2007. However, a few companies report on different dates varying from June 2007 to May 2008. In these cases we ensured all data is consistent with respect to the date of collection. Finally AMADEUS was used for information on companies' year of incorporation and the SIC industry classification.

\section{Method}

One of the serious complications in studying the relationship between board gender diversity and firm performance is that finding a correlation does not imply causality. The direction of causality 
can go both ways - meaning either that gender diversity leads to higher performance, or that high-performing companies tend to employ a more gender diverse workforce - and can thus imply joint endogeneity of the variables board gender diversity and firm performance. This issue has not been taken into consideration in many earlier studies. To control for the joint endogeneity and to be able to interpret results correctly, two-stage least-square (2SLS) estimation was applied.

Following Carter et al. (2003), we estimated the below-given system of simultaneous equations (1) and (2).

$$
\begin{aligned}
& \text { FirmPerformance }=\alpha_{o}+\alpha_{1} \text { BoardGenderDiversity }+\sum \alpha x+\varepsilon \\
& \text { BoardGenderDiversity }=\beta_{o}+\beta_{1} \text { FirmPerformance }+\sum \beta_{z}+v
\end{aligned}
$$

where $x$ and $z$ are vectors of control variables.

For the interpretation of results, a significant positive coefficient estimate $\left(\alpha_{1}>0\right)$ will confirm our research hypothesis. If our hypothesis is rejected, firm performance may either be negatively affected by board gender diversity (in that case the estimated coefficient of $\alpha_{1}$ is negative) or the presence of females on board of directors has no association with firm performance (in that case the estimated coefficient of $\alpha_{1}$ is zero or insignificant).

\section{Variables}

\section{Firm performance}

There are several ways of measuring firm performance and there is hardly any agreement on which is the most efficient one. Two main types of performance indicators have been widely used in corporate governance research: market-based ones (e.g. Tobin's Q and portfolio returns), and financial statement ratios (e.g. Return on Equity [ROE], Return on Assets [ROA], or Return on 
Investment [ROI]). Rose (2007) maintained that measures of performance such as the accounting-based ROE and ROA largely depend on the asset-valuation method, and concluded that Tobin's Q is the predominant measure used in corporate governance research and, even though not flawless, is relatively easy to interpret. We therefore used Tobin's Q, which is the ratio of the market value of a firm to the replacement cost of its assets. An excess of the firm's market value over its replacement costs (meaning a value of Tobin's Q greater than 1), suggests that the firm has intangible assets associated with future growth opportunities (Sudarsanam 2003). More specifically, following Brav, Jiang, Partnoy and Thomas (2008), we calculated Tobin's Q as the market value of equity plus book value of debt, all divided by book value of debt plus book value of equity.

\section{Board gender diversity}

Board gender diversity is measured in two ways: (1) Percentage of women on the board (management board plus supervisory board); and (2) Dummy variable indicating 1 if there is at least one woman on the board, or zero otherwise.

\section{Control variables affecting firm performance}

A first control variable is board size. As reviewed by Hermalin and Weisbach (2003), corporate governance research revealed the existence of a predominantly negative association between board size and firm performance, whereas an inverse association between board size and Tobin's Q was found by Yermack (1996), and Carter et al. (2003).

Secondly, the share of independent directors is included as a control variable. Whether independent directors bring value is an issue related to the agency problem between owners and managers, as first studied by Berle and Means (1932). Consequently, the performance-related 
effect of independent board directors has been broadly investigated in corporate governance research with mixed results (e.g. Baysinger and Butler 1985; Van Ees, Postma and Sterken 2003). The Dutch Corporate Governance Code recommends that, with the exception of one, all supervisory directors have to be independent (Corporate Governance Committee 2003). In the majority of companies, however, all supervisory directors are independent (Van Ees, Hooghiemstra, Van der Laan and Veltrop 2007). Therefore, for the Dutch companies, the share of independent directors on board was simply calculated as the number of supervisory directors divided by the total number of board members. In Denmark, at least half of the supervisory directors elected by the General Meeting of shareholders should be independent (Committee on Corporate Governance 2005). In addition, employees may elect supervisory board members when the total number of employees exceeds 35 , with a minimum of two and a maximum of half the number of supervisory directors (Knudsen 2006). For the Danish companies we therefore used the actual share of independent directors. ${ }^{1}$

In addition, firm size, firm age and industry were included as standard control variables. Firm size is measured by the natural logarithm of the net sales of the firm. Firm age is measured as the number of years the company exists in 2007. Regarding industry, the companies were grouped into three categories: (1) manufacturing, mining and construction (MANMC; 71 companies); (2) transportation, communications, wholesale- and retail trade (TCWRT; 34 companies); and (3) financial (except for banks and insurance), real estate, business, amusement and recreational, legal and accounting, management, research, development and testing services (SERVICE; 81 companies). Finally we included a country dummy variable equal to 1 in case a company is Dutch, or zero otherwise. 


\section{Control variables affecting board diversity}

A first control variable for board diversity is the age of the supervisory directors. Both in the Netherlands and in Denmark the supervisory board has a considerable weight in the nomination of supervisory directors and management directors. We assume that the younger the supervisory directors, the less the impact of the 'old boys network' might be, resulting in a higher probability of women being appointed on board. A second control variable is firm size (see above). As larger firms are more in the public eye and thus under more societal pressure for board diversity (Adams and Ferreira 2004), firm size is expected to have a positive impact on board gender diversity. In addition we included the standard controls firm age, industry, and the country dummy.

All variables used are summarised in table 1.

- Table 1 about here -

\section{Results}

The companies in our sample have a total of 1454 board positions and women occupy 93 director seats. The majority of female directors held non-executive (supervisory) positions (82); there were only 11 female executive directors. Women occupy $8 \%$ of all 1026 non-executive director seats and $2.6 \%$ of all 428 executive positions. The percentage of companies with at least one female director in our total sample is $36.6 \%$ (25.5\% for the Netherlands and $50 \%$ for Denmark). Table 2 presents descriptive statistics of key variables from our sample. The average board consists of 7.8 directors, with a minimum of three and a maximum of 18 members. The average share of women on board is $5.4 \%$ and the highest percentage of women on the board found is 
$40 \%$. Of the total board $55.1 \%$ are independent directors and these directors are, on average, 57.4 years old. The average value of Tobin's Q is 2.30, with a standard deviation of 1.70 .

- Table 2 about here -

A comparison between the two countries indicates that Denmark appears to have larger boards of directors and on average more women on board. These results seem in line with Randøy et al. (2006) who argue that the regulation regarding employee representation in Denmark adds to both board size and board diversity. In the Netherlands the share of independent directors is higher, reflecting the difference in corporate governance recommendations. Moreover, supervisory directors in the Netherlands are, on average, 5 years older than those in Denmark. Size of boards does not appear to be associated with company size, as the average Dutch company in our sample is larger than its Danish counterpart (see appendix for more details).

Table 3 presents a general comparison of the mean values of the key variables for companies with at least one female director on the board and companies with no female directors on the board. In 118 out of the 186 companies in the sample there were no women directors $(63.4 \%)$. The companies with at least one female director on the board had, on average, more directors on their boards, a higher value of Tobin's Q, and were larger. In addition, they also had less independent directors on their boards and younger supervisory directors as compared to the companies without female directors.

- $\quad$ Table 3 about here - 
The results from the 2SLS estimation are reported in table 4. In the first model the dependent variables are Tobin's Q (1a) and board gender diversity as measured by the percentage of women (1b). In addition, a second model (2) was tested in which a dummy variable is used for board gender diversity, indicating 1 if there is at least one woman on the board.

- Table 4 about here -

Table 4 indicates that the estimated coefficients for board gender diversity are positive, but statistically insignificant. This implies that the business case argument for board diversity is not supported for this particular sample. Regarding Tobin's Q a variable that matters in both models is firm age. Firm age is found to be negatively associated with performance in both models (1a) and (2a), which may be related to the weakening ability over time of firms to compete, as argued by Loderer and Waelchli (2009). In addition, the share of independent directors also appeared to negatively affect firm performance in model (2a), where a dummy for board gender diversity is used. This finding is consistent with Van Ees et al. (2003). Regarding the share of women on boards of directors, it matters if the company is Dutch or Danish, with Dutch companies having less women on their boards.

In conclusion, based on our sample and 2SLS estimation, our findings do not provide evidence that there is a relation between board gender diversity and firm performance. Apparently, within Dutch and Danish boardrooms having (more) women on board of directors does not result in a better firm performance. While in line with most findings in similar European 
studies (e.g. Randoy et al. 2006; Rose 2007), the results should be interpreted with caution as the sample is limited to listed companies in two small countries.

\section{Conclusions and discussion}

The role of women as board directors and top corporate executives in driving firm performance has become a very topical issue. Especially in the current times of economic crisis which is largely attributed to unsound risk management practices, there is debate if the global economic picture would have looked less grim, had there been more women on boards of directors in the distressed financial institutions. The proponents refer in this respect to the fact that women are more risk-averse and claim that more gender diverse corporate teams will help bring the global economy back on track. These arguments strongly relate to the business case for board gender diversity, which has been investigated empirically in this article. As such the article adds to the limited European evidence on the effect of board gender diversity on firm performance. Drawing on the development in organizational strategy and corporate governance over recent years, which approaches women's representation in top corporate positions as a value-driver, the hypothesis in our study is that board gender diversity will lead to positive firm performance effects. It appears, however, that the business case for board gender diversity is not supported by our sample of 186 listed firms in the Netherlands and Denmark.

Rather than providing final answers, our study should be considered a useful starting point for further research. Future studies may include more variables than our study could, in particular variables referring to board characteristics. In addition, it seems useful to extend samples by including non-listed companies. In this case, instead of a market-based performance 
measure (Tobin's Q), an accounting-based measure should be used (e.g. ROA). Finally, future research should focus on panel data in order to deal with the limitation of studying a single year. If gender-related performance effects can be traced over several years, the quality and implications of the analysis will improve considerably, as dynamic factors will also be captured in the relationship. In addition, it seems interesting to extend the scope of research by focusing on two particular performance events: mergers and acquisitions (M\&A) and bankruptcies. As these two specific events that can be unambiguously classified as either success or failure, such a research design will allow to infer causality in the relationship between board gender diversity and firm performance.

Furthermore, in most empirical studies so far, including the study described in this article, the business case is investigated on a rather general level without examining actual differences between male and female board members and the dynamics within the board. The scarcity of research on the underlying mechanisms and moderating effects in the relationship between board gender diversity and firm performance pinpoints the need for more efforts in this direction. Particularly investigating possible gender differences in risk-propensity, which moderates the relationship between directors' characteristics and firm performance, may be a fruitful direction for future research. There is extensive evidence that women are more risk-averse than men (e.g. Byrnes, Miller and Schafer 1999; Dohmen et al. 2005). Croson and Gneezy (2009), however, show that among the population of managers and professionals gender differences in risk taking are smaller and often nonexistent. This could be the result of selection; people that are more risk taking tend to choose managerial positions and there are no differences in this respect between men and women However, within firms there might also be assimilation processes through which women 'mask' specific gender-related propensities in order to reach board positions. Case- 
studies seem an appropriate approach for studying the possible gendered nature of decision making. It will be a particular challenge, though, to persuade companies to open up their boardrooms for this end.

A final remark refers to female participation in top management. In the current discussions there is a strong emphasis on the business case as an argument in favour of more women in top positions. .. In should be taken into account, though, that an equal representation of women in top positions is not only a means to an end, but also a matter of social justice and therefore an argument as such.

\section{Notes}

${ }^{1}$ In case exact data were missing, we applied the following procedure. If compliance with the corporate governance recommendation was stated in companies' annual reports or website, we considered half of the directors elected by the General Meeting as independent. In case of noncompliance, we took half the number of total supervisory directors elected by the General Meeting minus one to calculate the share of independent directors.

\section{References}

Adams, R.B, and Ferreira, D. (2004), 'Gender Diversity in the Boardroom', Working Paper, Stockholm School of Economics, available at: http://www.skinance.com/Papers/2005/RBA.pdf

Adler, R.D. (2001), 'Women in the Executive Suite Correlate to High Profits', Working paper, Malibu CA: Pepperdine University, available at: http://www.equalpay.nu/en_fakta.html Ancona, D.G, and Caldwell, D.F. (1992), 'Demography and Design: Predictors of New Product 
Team Performance, Organization Science, 3, 3, 321-341.

Baysinger, B.D., and Butler, H.N. (1985), 'Corporate Governance and the Board of Directors:

Performance Effects of Changes in Board Composition', Journal of Law, Economics and Organization, 1,1, 101-124.

Becht, M., Bolton, P., and Röell, A. (2002), 'Corporate Governance and Control', ECGI Finance working paper No. 02/2002, available at SSRN:

http://ssrn.com/abstract=343461

Berle, A.A., and Means, G.C. (1932), The Modern Corporation and Private Property. New York: Macmillan.

Bøhren, Ø., and Strøm, R.Ø. (2007), 'Aligned, Informed, and Decisive: Characteristics of ValueCreating Boards', EFA 2007 Ljubljana Meetings Paper, available at SSRN: http://ssrn.com/abstract $=966407$

Brav, A., Jiang, W., Partnoy, F., and Thomas, R. (2008), 'Hedge Fund Activism, Corporate Governance, and Firm Performance', The Journal of Finance, 63,4, 1729-1775.

Byrnes, J.P., Miller, D.C., and Schafer, W.D. (1999), 'Gender Differences in Risk-Taking: A Meta-Analysis', Psychological Bulletin, 125, 3, 367-383.

Carter, D.A., Simkins, B.J., and Simpson, W.G. (2003), 'Corporate Governance, Board Diversity and Firm Value', The Financial Review, 38,1, 33-53.

Carter, D.A., D’Souza, F.P, Simkins, B.J., and Simpson, W.G. (2008), 'The Diversity of Corporate Board Committees and Financial Performance', available at SSRN: http://ssrn.com/abstract $=1106698$

Catalyst (2004), 'The Bottom Line: Connecting Corporate Performance and Gender Diversity, New York, NY, available at: http://www.catalyst.org/ 
Committee on Corporate Governance (2005), Recommendations for Corporate Governance of August 15, 2005, available at: http://www.corporategovernance.dk/ Corporate Governance Committee (2003), The Dutch Corporate Governance Code. Principles of Good Corporate Governance and Best Practice Provisions, 9 December 2003, available at: http://www.corpgov.nl/

Croson, R. and Gneezy, U. (2009), 'Gender Differences in Preferences', Journal of Economic Literature, 47, 2, 448-474.

Desvaux, G., Devillard-Hoellinger, S., and Meaney, M.C. (2008), ‘A Business Case for Women', McKinsey Quarterly, available at: http://www.mckinseyquarterly.com/

Dezso, C.L., and Ross, D.G. (2008), “'Girl Power:” Female Participation in Top Management and Firm Performance', Robert H. Smith School Research paper No. RHS 06-104, available at SSRN: http://ssrn.com/abstract=1088182

Dohmen, T., Falk, A., Huffman, D., Sunde, U., Schüp, J. and Wagner, G. (2005). 'Individual Risk Attitude: New Evidence From a Large Representative, Experimentally-Validated Survey', IZA Discussion Papers No. 1730, Bonn: IZA.

Dwyer, S., Richard, O.C., and Chadwick, K. (2003), 'Gender Diversity in Management and Firm Performance: The Influence of Growth Orientation and Organizational Culture', Journal of Business Research, 56,12, 1009-1019.

Eisenberg, T., Sundgren, S., and Wells, M.T. (1998), 'Larger Board Size and Decreasing Firm Value in Small Firms', Journal of Financial Economics, 48,1, 35-54.

Erhardt, N.L., Werbel, J.D., and Shrader, C.B. (2003), 'Board of Director Diversity and Firm Financial Performance', Corporate Governance: An International Perspective, 11,2, 102 111. 
EuropeanPWN. (2008), 'Third Bi-annual EuropeanPWN Board Women Monitor 2008', Press release 27 June 2008, available at: http://www.europeanpwn.net/

Frink, D.D., Robinson, R.K., Reithel, B., Arthur, M.M., Ammeter, A.P., Ferris, G.R., Kaplan, D.M., and Morrisette, H.S. (2003), 'Gender Demography and Organization Performance: A Two-study Investigation with Convergence', Group and Organization Management, $28,1,127-147$.

Hambrick, D.C., Cho, T.S., and Chen, M.J. (1996), ‘The Influence of Top Management Team Heterogeneity on Firms' Competitive Moves', Administrative Science Quarterly, 41,4, $659-684$.

Hermalin, B.E., and Weisbach, M. S. (2003), 'Boards of Directors as an Endogenously Determined Institution: A Survey of the Economic Literature', Economic Policy Review, $9,1,7-26$.

Jackson, S.E. (1992), 'Consequence of Group Composition for the Interpersonal Dynamics of Strategic Issue Processing', in Advances in Strategic Management, eds. P. Shrivastava, A. Huff and J. Dutton, Greenwich, CT: JAI Press, vol. 8: pp. 345-382.

Jensen, M.C. (1993), 'The Modern Industrial Revolution, Exit, and the Failure of Internal Control Systems', The Journal of Finance, 48,3, 831-880.

Knudsen, H. (2006), The Provisions on Company Management in the Danish Law on Public Limited Companies (Aktieselskabsloven), Denmark: Aalborg Univeristy, available at: http://www.seeurope-network.org

Kochan, T., Bezrukova, K., Ely, R., Jackson, S., Joshi, A., Jehn, K., Leonard, J., Levine, D., and Thomas, D. (2003), 'The Effects of Diversity on Business Performance: Report of the Diversity Research Network', Human Resource Management, 42,1, 3-21. 
Levi, M., Li, K., and Zhang, F. (2008), 'Mergers and Acquisitions: The Role of Board Gender Diversity', available at SSRN: http://ssrn.com/abstract=1123735

Loderer, C.F., and Waelchli, U. (2009), 'Firm Age and Performance', available at SSRN: http://ssrn.com/abstract $=1342248$

Randøy, T., Thomsen, S., and Oxelheim, L. (2006), 'A Nordic Perspective on Corporate Board Diversity', Nordic Innovation Centre, Oslo, available at: http://www.nordicinnovation.net/

Rose, C. (2007), 'Does Female Board Representation Influence Firm Performance? The Danish Evidence. Corporate Governance, 15,2, 404-413.

Smith, N., Smith, V., and Verner, M. (2006), 'Do Women in Top Management Affect Firm Performance? A Panel Study of 2,500 Danish Firms', International Journal of Productivity and Performance Management, 55,7, 569-593.

Sudarsanam, S. (2003), Creating Value from Mergers and Acquisitions: The Challenges, London: Financial Times Prentice Hall.

Sudarsanam, S., and Huang, J. (2007), 'Gender Diversity in US Top Management: Impact on Risk-Taking and Acquirer Performance', available at EFMA: http://www.efmaefm.org/

Van Ees, H., Postma, T.J.B.M., and Sterken, E. (2003), 'Board Characteristics and Corporate Performance in the Netherlands', Eastern Economic Journal, 29,1, 41-58.

Van Ees, H., Hooghiemstra, R.B.H., Van der Laan, G. and Veltrop, D. (2007), 'Diversiteit binnen de Raden van Commissarisen van Nederlandse Beursgenoteerde Vennootschappen', Groningen: Rijksuniversiteit Groningen/Corporate Governance Insight Centre.

Weber, A., and Zulehner, C. (2009), 'Female Hires and the Success of Start-Up Firms', Ruhr 
Economic Paper No. 151, available at SSRN:

http://papers.ssrn.com/sol3/papers.cfm?abstract_id=1514366

Wilson, N., and Altanlar, A. (2009). 'Director Characteristics, Gender Balance and Insolvency Risk: An Empirical Study', Abstract May 2009, available at SSRN:

http://ssrn.com/abstract=1414224

Yermack, D. (1996), 'Higher Market Valuation of Companies With a Small Board of Directors, Journal of Financial Economics 40,2, 185-211. 


\section{Appendix}

Table 1 . Mean values of key variables, by country

\begin{tabular}{lccc}
\hline Mean values & The Netherlands & Denmark & t-test \\
\hline Share of women on board & 0.038 & 0.074 & $3.033^{* * *}$ \\
Tobin's Q & 2.139 & 2.495 & 1.426 \\
Board size & 7.255 & 8.500 & $2.871^{* * *}$ \\
Share of independent directors & 0.657 & 0.424 & $-12.241^{* * *}$ \\
Average age of supervisory directors & 59.754 & 54.640 & $-7.397^{* * *}$ \\
Firm Size & 12.856 & 11.288 & $-4.268^{* * *}$ \\
\hline Number of firms & 102 & 84 & \\
\hline
\end{tabular}

*** Indicates statistical significance between countries at the 0.01 level. 
Tables to be inserted in the text

Table 1 Variables definitions

\begin{tabular}{|c|c|}
\hline Variable & Definition \\
\hline Tobin's Q & $\begin{array}{l}\text { (Market Value Equity + Book Value Total Debt) / (Book Value } \\
\text { Equity + Book Value Total Debt) }\end{array}$ \\
\hline Board gender diversity $(\%)$ & $\begin{array}{l}\text { The number of female directors on Board as a proportion of all } \\
\text { directors on board }\end{array}$ \\
\hline Board gender diversity $(1 / 0)$ & $\begin{array}{l}\text { Dummy variable }=1 \text { if there is at least } 1 \text { woman on board; } 0 \\
\text { otherwise }\end{array}$ \\
\hline Board size & The total number of directors \\
\hline Share of supervisory directors & $\begin{array}{l}\text { The number of supervisory directors as proportion of all } \\
\text { directors on board }\end{array}$ \\
\hline Average age of supervisory directors & $\begin{array}{l}\text { The average age of supervisory directors calculated as the sum of } \\
\text { the ages of all supervisory directors divided by the number of all } \\
\text { supervisory directors }\end{array}$ \\
\hline Firm size & The natural logarithm of the net sales of the firm \\
\hline Firm age & $\begin{array}{l}\text { The number of years of firm's existence (as at 31.12.2007) since } \\
\text { year of incorporation }\end{array}$ \\
\hline Industry dummy MANMC & $\begin{array}{l}\text { Dummy variable }=1 \text { indicating a company is in the } \\
\text { manufacturing, mining and construction group of industries; } 0 \\
\text { otherwise }\end{array}$ \\
\hline Industry dummy TCWRT & $\begin{array}{l}\text { Dummy variable }=1 \text { indicating a company is in the transportation, } \\
\text { communications, wholesale- and retail trade group of industries; } \\
0 \text { otherwise }\end{array}$ \\
\hline Industry dummy SERVICE & $\begin{array}{l}\text { Dummy variable }=1 \text { indicating a company is in the service group } \\
\text { of industries; } 0 \text { otherwise }\end{array}$ \\
\hline Country dummy DUTCH & Dummy variable $=1$ indicating a company is Dutch; 0 otherwise \\
\hline
\end{tabular}


Table 2 Descriptive values of key variables

\begin{tabular}{lcccc}
\hline Variable & Mean & $\begin{array}{c}\text { Standard } \\
\text { Deviation }\end{array}$ & Min & Max \\
\hline Share of women on board & 0.054 & 0.080 & 0.000 & 0.400 \\
Tobin's Q & 2.299 & 1.701 & 0.654 & 11.823 \\
Board size & 7.817 & 3.001 & 3 & 18 \\
Share of independent directors & 0.551 & 0.173 & 0.000 & 0.857 \\
Average age supervisory directors & 57.445 & 5.331 & 38.830 & 68.000 \\
Firm size & 12.148 & 2.609 & 2.596 & 17.509 \\
\hline Total number of firms: 186 & & & &
\end{tabular}

Total number of firms: 186 
Table 3 Mean values of key variables for companies with and without female directors (standard deviation)

\begin{tabular}{lc|c}
\hline Mean values & $\begin{array}{c}\text { Companies with at least } \\
\text { one woman on board }\end{array}$ & $\begin{array}{c}\text { Companies without } \\
\text { women on board }\end{array}$ \\
\hline Tobin's Q & $2.671(1.969)$ & $2.085(1.492)$ \\
Board size & $9.618(3.105)$ & $6.780(2.397)$ \\
Share of independent directors & $0.519(0.182)$ & $0.570(0.166)$ \\
Average age of supervisory directors & $56.330(4.554)$ & $58.087(5.649)$ \\
Firm size & $12.888(2.669)$ & $11.722(2.486)$ \\
\hline Total number of firms & 68 & 118 \\
\hline
\end{tabular}


Table 4 Results of the 2SLS estimation of the relationship between firm performance and board gender diversity (standard errors reported in parentheses)

\begin{tabular}{|c|c|c|c|c|}
\hline Independent variables & $\begin{array}{l}\text { Tobin's Q } \\
\text { (1a) }\end{array}$ & $\begin{array}{l}\text { Board } \\
\text { gender } \\
\text { diversity } \\
(\%) \\
(1 b) \\
\end{array}$ & $\begin{array}{l}\text { Tobin's Q } \\
(2 a)\end{array}$ & $\begin{array}{l}\text { Board } \\
\text { gender } \\
\text { diversity } \\
(1 / 0) \\
(2 b) \\
\end{array}$ \\
\hline Constant & $\begin{array}{c}4.5277 * * * \\
(1.5307)\end{array}$ & $\begin{array}{l}-0.1930 \\
(0.2324)\end{array}$ & $\begin{array}{c}4.7183 * * * \\
(1.5077)\end{array}$ & $\begin{array}{l}-2.7599 \\
(2.2032)\end{array}$ \\
\hline Board gender diversity (\%) & $\begin{array}{c}22.6394 \\
(15.4195)\end{array}$ & & & \\
\hline Board gender diversity $(1 / 0)$ & & & $\begin{array}{c}3.5914 \\
(2.2679)\end{array}$ & \\
\hline Board size & $\begin{array}{l}-0.0930 \\
(0.1448)\end{array}$ & & $\begin{array}{l}-0.1773 \\
(0.1811)\end{array}$ & \\
\hline Share of independent directors & $\begin{array}{l}-3.4826 \\
(2.2086)\end{array}$ & & $\begin{array}{l}-3.1355^{*} \\
(1.8794)\end{array}$ & \\
\hline $\begin{array}{l}\text { Average age of supervisory } \\
\text { directors }\end{array}$ & & $\begin{array}{c}0.0013 \\
(0.0029)\end{array}$ & & $\begin{array}{c}0.0232 \\
(0.0272)\end{array}$ \\
\hline Firm size & $\begin{array}{l}-0.0921 \\
(0.1009)\end{array}$ & $\begin{array}{c}0.0053 \\
(0.0040)\end{array}$ & $\begin{array}{l}-0.0797 \\
(0.0908)\end{array}$ & $\begin{array}{c}0.0341 \\
(0.0378)\end{array}$ \\
\hline Firm age & $\begin{array}{c}-0.0064 * \\
(0.0034)\end{array}$ & $\begin{array}{c}0.0003 \\
(0.0002)\end{array}$ & $\begin{array}{c}-0.0054 * \\
(0.0029)\end{array}$ & $\begin{array}{c}0.0026 \\
(0.0020)\end{array}$ \\
\hline Industry dummy $1=$ MANMC & $\begin{array}{l}-0.2395 \\
(0.4274)\end{array}$ & $\begin{array}{c}0.0166 \\
(0.0213)\end{array}$ & $\begin{array}{l}-0.1575 \\
(0.4071)\end{array}$ & $\begin{array}{c}0.1664 \\
(0.2024)\end{array}$ \\
\hline Industry dummy $1=$ TCWRT & $\begin{array}{l}-0.3302 \\
(0.5326)\end{array}$ & $\begin{array}{c}0.0181 \\
(0.0320)\end{array}$ & $\begin{array}{l}-0.0869 \\
(0.5629)\end{array}$ & $\begin{array}{c}0.2149 \\
(0.3033)\end{array}$ \\
\hline Industry dummy SERVICE (Ref.) & - & - & - & - \\
\hline Country dummy $1=\mathrm{DUTCH}$ & $\begin{array}{c}1.5130 \\
(1.0124)\end{array}$ & $\begin{array}{c}-0.0454 * * \\
(0.0182)\end{array}$ & $\begin{array}{c}1.3426 \\
(0.8462)\end{array}$ & $\begin{array}{c}-0.3267 * \\
(0.1723)\end{array}$ \\
\hline Tobin's Q & & $\begin{array}{c}0.0471 \\
(0.0385)\end{array}$ & & $\begin{array}{c}0.5697 \\
(0.3653)\end{array}$ \\
\hline $\mathrm{N}$ & 186 & 186 & 186 & 186 \\
\hline F-Statistic & 1.19 & 2.09 & 1.39 & 1.47 \\
\hline
\end{tabular}

* Indicates statistical significance at the 0.10 level.

** Indicates statistical significance at the 0.05 level.

*** Indicates statistical significance at the 0.01 level. 